\title{
Perbandingan Kadar CD4 dan Total Lymphocyte Count dengan Kombinasi Highly Active Antiretroviral Therapy pada Pasien HIV/AIDS di RSUP Dr.Kariadi Semarang
}

Iraisa Rosaria ${ }^{1}$, Purwanto Adipireno²

\begin{abstract}
Abstrak
Tujuan: Membuktikan perbedaan jenis pemberian kombinasi Highly Active Antiretroviral Therapy dengan perubahan kadar CD4 dan Total Lymphocyte Count pada pasien HIV/AIDS di RSUP Dr. Kariadi Semarang. Metode: Penelitian ini bersifat analitik yang dilakukan dengan rancangan studi potong lintang. Sampel diambil secara total sampling, yaitu seluruh pasien HIV/AIDS yang berobat di RSUP Dr. Kariadi Semarang selama 2018 sampai 2019 yang memenuhi kriteria inklusi dan mendapat pengobatan salah satu dari kombinasi Highly Active Antiretroviral Therapy (HAART). Keenam jenis kombinasi HAART tersebut adalah kombinasi I (Efavirens+ Lamivudin+ Tenofovir), II (Evafirenz+ Lamivudin+Zidovudin), III(Nevirapine+Lamivudin+ Tenofovir), IV (Lamivudine+Zidovudine+Nevirapine), V (Lamivudine+Tenofovir+Rilvipirine), VI (Tenofovir+Rilvipirine+Emtricitabine). Data dikumpulkan dari rekam medis pasien dan dianalisis dengan uji Kruskal-Wallis. Hasil: Dari 89 pasien, didapatkan keenam kombinasi HAART tersebut memberikan efikasi yang baik berdasarkan kenaikan jumlah CD4 dan TLC rerata. Ada perbedaan kenaikan CD4 rerata yang bermakna pada pasien HIV/AIDS antara yang mendapat obat HAART kombinasi I $(p=0,038)$, II $(p=$ $0,034)$, IV $(p=0,001), V(p=0,040)$, VI $(p=0,006)$. Pada Total Lymphocyte Count (TLC) didapatkan perbedaan kenaikan rerata $(p<0,05)$ pada semua kombinasi HAART. Simpulan: Tidak ada perbedaan jenis pemberian kombinasi Highly Active Antiretroviral Therapy dengan perubahan kadar CD4 dan Total Lymphocyte Count $(p>0,05)$ pada pasien HIV / AIDS di RSUP Dr. Kariadi Semarang.
\end{abstract}

Kata kunci: $\mathrm{CD} 4$, highly active antiretroviral therapy, ODHA, total lymphocyte count

\begin{abstract}
Objectives: To proved the different types of combination administration of Highly Active Antiretroviral Therapy with changes in CD4 levels and Total lymphocyte counts of HIV / AIDS patients in Dr. RSUP Kariadi Semarang. Methods: This study analyzed analytics conducted by designing cross-sectional studies. The sample in this study was taken in total sampling, namely all HIV / AIDS patients who were treated at Dr. Kariadi Semarang during 2018-2019, that fulfilled the inclusion criteria and received treatment from one of the HAART combinations. These six types of Highly Active Antiretroviral Therapy (HAART) combinations are a combination of I (Efavirens + Lamivudin + Tenofovir), II (Evafirenz + Lamivudin + Zidovudin), III (Nevirapine + Lamivudin + Tenofovir), IV (Lamivudine + Zidovudine + Nevirapine + Nevirapine + Tenviovirine), VI (Tenofovir + Rilvipirine + Emtricitabine). Data were collected from the patient's medical record and analyzed by the Kruskal-Wallis test. Results: From 89 patients, this combination of HAART numbers provided good efficacy based on an increase in CD4 cell count and average Total Lymphocyte Count (TLC). There was a difference in the average CD4 increase that was beneficial in HIV / AIDS patients among those who received the HAART Combination drug $(p=0.038)$, II $(p=0.034), I V(p=0.001), V(p=0.040), V I$ ( $p$-value $=0.006)$. While for TLC, there was an average difference $(p<0.05)$ in all combination ART. Conclusion: There is no difference in the type of combination of Highly Active Antiretroviral Therapy with changes in CD4 levels and Total Lymphocyte Count ( $p>0.05$ ) in patients with HIV / AIDS in Dr. RSUP Kariadi Semarang.
\end{abstract}

Keywords: CD4, highly active antiretroviral therapy combination, ODHA, total lymphocyte count 
Affiliasi penulis: ${ }^{1}$ Program Pendidikan Dokter Spesialis Patologi Klinik, Fakultas Kedokteran, Universitas Diponegoro, Semarang. ${ }^{2}$ Bagian Patologi Klinik, Fakultas, Kedokteran, Universitas Diponegoro, Semarang

Korespondensi: Iraisa Rosaria, Email: cridoecat@yahoo.com Telp: 082132465665

\section{PENDAHULUAN}

Permasalahan HIV dan AIDS menjadi tantangan kesehatan hampir di seluruh dunia, termasuk di Indonesia. ${ }^{1}$ Sejak pertama kali ditemukan sampai dengan Juni 2018, HIV/ AIDS telah dilaporkan keberadaannya oleh $433 \quad(84,2 \%)$ dari 514 kabupaten/kota di 34 provinsi di Indonesia. Jumlah kumulatif infeksi HIV yang dilaporkan sampai dengan Juni 2018 sebanyak 301.959 jiwa (47\% dari estimasi ODHA jumlah orang dengan HIV AIDS tahun 2018 sebanyak 640.443 jiwa) dan paling banyak ditemukan di kelompok umur 25-49 tahun dan 20-24 tahun. Adapun provinsi dengan jumlah infeksi HIV tertinggi adalah DKI Jakarta (55.099), diikuti Jawa Timur (43.399), Jawa Barat (31.293), Papua (30.699), dan Jawa Tengah (24.757). ${ }^{2}$ Jumlah kasus HIV yang dilaporkan terus meningkat setiap tahun, sementara jumlah AIDS relatif stabil. Hal ini menunjukkan keberhasilan bahwa semakin banyak orang dengan HIV /AIDS (ODHA) yang diketahui statusnya saat masih dalam fase terinfeksi (HIV positif) dan belum masuk dalam stadium AIDS. ${ }^{3}$

Pedoman tatalaksana HIV dan pengobatan antiretroviral telah lama tersedia dan terus menerus diperbarui sesuai dengan perkembangan ilmu pengetahuan, untuk digunakan sebagai pedoman dalam memberi layanan kepada ODHA. ${ }^{4}$ Makin bertambahnya jumlah kasus HIV dan meningkatnya kebutuhan akan adanya akses layanan yang menyebar secara luas sehingga semua orang dengan HIV dapat dengan mudah memulai ARV di dekat lingkungan tinggalnya maka akses layanan perlu didekatkan ke masyarakat. Beberapa propinsi seperti DKI, Jawa Barat, Jawa Timur, Bali, Papua dan Papua Barat berinisiatif menjadikan Puskesmas sebagai satelit untuk pengobatan ARV dari rumah sakit dalam kerangka kerja Layanan HIV-IMS Komprehensif Berkesinambungan (LKB). ${ }^{2,5}$ Diperlukan suatu pedoman dalam melaksanakan program pengendalian dan layanan HIV AIDS dan PIMS dengan baik. ${ }^{3}$
Upaya pencegahan dan pengendalian HIV -AIDS bertujuan untuk mewujudkan target Three Zero pada 2030, yaitu: 1) Tidak ada lagi penularan infeksi baru HIV, 2) Tidak ada lagi kematian akibat AIDS, dan 3) Tidak ada lagi stigma dan diskriminasi pada orang dengan HIV AIDS (ODHA). Strategi Fast Track 90-9090 yang meliputi: mempercepat pencapaian $90 \%$ dari orang yang hidup dengan HIV (ODHA) mengetahui status HIV mereka melalui tes atau deteksi dini; $90 \%$ dari ODHA yang mengetahui status HIV untuk memulai terapi pengobatan ARV) dan 90\% ODHA yang dalam pengobatan ARV telah berhasil menekan jumlah virusnya sehingga mengurangi kemungkinan penularan HIV; serta tidak ada lagi stigma dan diskriminasi ODHA. ${ }^{6,7,8}$ Dalam rangka mencapai target Fast Track 90-90-90, Kementerian Kesehatan juga menggaungkan strategi akselerasi Suluh, Temukan, Obati dan Pertahankan (STOP) untuk mencapai target tahun 2030 tersebut. Tahun ini, diluncurkan pula strategi Test and Treat, yaitu ODHA dapat segera memulai terapi ARV begitu terdiagnosis mengidap HIV. $^{9}$

Pemeriksaan CD4 digunakan untuk menilai derajat imunodefisiensi dan menentukan perlunya pemberian profilaksis. Walaupun terapi ARV saat ini diindikasikan pada semua ODHA tanpa melihat jumlah CD4-nya, pemeriksaan jumlah CD4 awal tetap dianggap penting, apalagi di Indonesia di mana masih banyak ODHA yang didiagnosis HIV pada kondisi lanjut. ${ }^{10}$ Jumlah CD4 diperlukan untuk menentukan indikasi pemberian profilaksis infeksi oportunistik. Stadium klinis juga tidak selalu sesuai dengan jumlah CD4 seseorang. ${ }^{11,12}$

Penyedia layanan kesehatan di daerah yang terbatas sumber daya mungkin tidak memiliki akses ke pemeriksaan laboratorium CD4 atau biayanya mungkin mahal, yang mengakibatkan perlunya alternatif marker pengganti. ${ }^{13,14}$ Mengingat penurunan biaya dan peningkatan ketersediaan terapi antiretroviral (ART) di negara berkembang, penilaian penanda diagnostik laboratorium yang murah dan sederhana adalah wajib untuk mendiagnosis imunosupresi. ${ }^{15}$

Pedoman World Health Organization menganjurkan penggunaan TLC sebagai penanda pengganti untuk jumlah CD4. ${ }^{6}$ Sejumlah penelitian 
sebelumnya menunjukkan bahwa jumlah limfosit total (TLC) mungkin berguna sebagai marker pengganti status kekebalan. ${ }^{16}$ Kontroversi mengenai TLC tetap ada. Idealnya, titik batas TLC 2.000 sel / mm3 dapat digunakan dalam pengaturan di mana sumber daya seperti ART dan pemantauan laboratorium terjangkau dan tersedia. ${ }^{13}$ Dalam pengaturan terbatas sumber daya, maka hal ini tidak terjadi, keuntungannya dan kelemahan dari masing-masing pendekatan memperdebatkan penggunaan yang lebih rendah. ${ }^{17}$ TLC tampaknya setara dengan jumlah sel CD4 dalam pemantauan tanggapan terhadap terapi dan dengan tidak adanya tes viral load, informasi yang tersedia menunjukkan hal ini dapat berfungsi sebagai pengganti yang murah untuk jumlah CD4. ${ }^{18}$ Algoritma juga dapat dapat dikembangkan dengan menggunakan beberapa pengukuran TLC bersamaan dengan pengukuran jumlah CD4 sesekali, dapat memberikan cara yang lebih murah untuk memandu terapi dan manajemen HIV. ${ }^{19,20}$

\section{METODE}

Penelitian ini merupakan suatu analitik observasional dengan pendekatan belah lintang (cross sectional). pengambilan data dilakukan secara retrospektif terhadap data sekunder berupa rekam medis pasien. Subjek penelitian adalah penderita HIV/AIDS yang berobat di RSUP Dr. Kariadi Semarang secara consecutive sampling pada bulan Mei 2018 - Mei 2019 yang memenuhi kriteria inklusi dan eksklusi penelitian. Kriteria inklusi adalah pasien HIV (+), berusia $\geq 18$ tahun, jumlah CD4 awal $<350$ sel/mm3, mendapat salah satu kombinasi ARV, memiliki data hasil pemeriksaan jumlah CD4 awal dan data CD4 evaluasi, TLC awal dan TLC evaluasi. Kriteria eksklusi adalah data pasien yang tidak lengkap, lost to follow up.

Pemeriksaan parameter CD4 menggunakan BD FACS dan parameter leukosit dengan CELL DYN 1800 Flow Cytometry, nilai TLC didapatkan dari perkalian persen neutrofil dengan jumlah leukosit.

Data yang diinginkan kemudian diambil ke lembar pengumpul data variabel yang diteliti berupa kombinasi ARV sebagai variabel bebas dan kenaikan jumlah CD4 rata-rata dan TLC rata-rata berupa variabel terikat. Masing- masing kombinasi ARV dilihat efikasinya berdasarkan kenaikan jumlah CD4 rata-rata setelah pemberian ARV enam bulan. Data yang didapat dianalisis dengan menggunakan uji Anova.

Seluruh data hasil penelitian ditampilkan dalam bentuk karakteristik umum (deskriptif). Uji normalitas data menggunakan Kolmogorov Smirnov, didapatkan distribusi data tidak normal. Uji beda berpasangan CD4 awal dan evaluasi, TLC awal dan evaluasi menggunakan uji Wilcoxon signed ranks test. Analisis statistik diolah menggunakan program komputer, nilai p bermakna bila $<0,05$ dengan interval kepercayaan $95 \%$.

Efikasi 6 jenis kombinasi ARV ditinjau dari kenaikan jumlah CD4 rata-rata dan TLC rata-rata hasil penelitian, sebagian besar pasien HIV/AIDS memperlihatkan kenaikan jumlah CD4 setelah mendapat pengobatan ARV 6 bulan. Keenam kombinasi ARV yang di gunakan memiliki efikasi yang baik, karena memberikan kenaikan CD4 > 50 sel/mm3, kenaikan jumlah CD4 pasien baru HIV/AIDS setelah 6 bulan pengobatan ARV di RSUP Dr.Kariadi Semarang. 
HASIL

Tabel 1. Uji beda berpasangan CD4 awal dan CD4 evaluasi

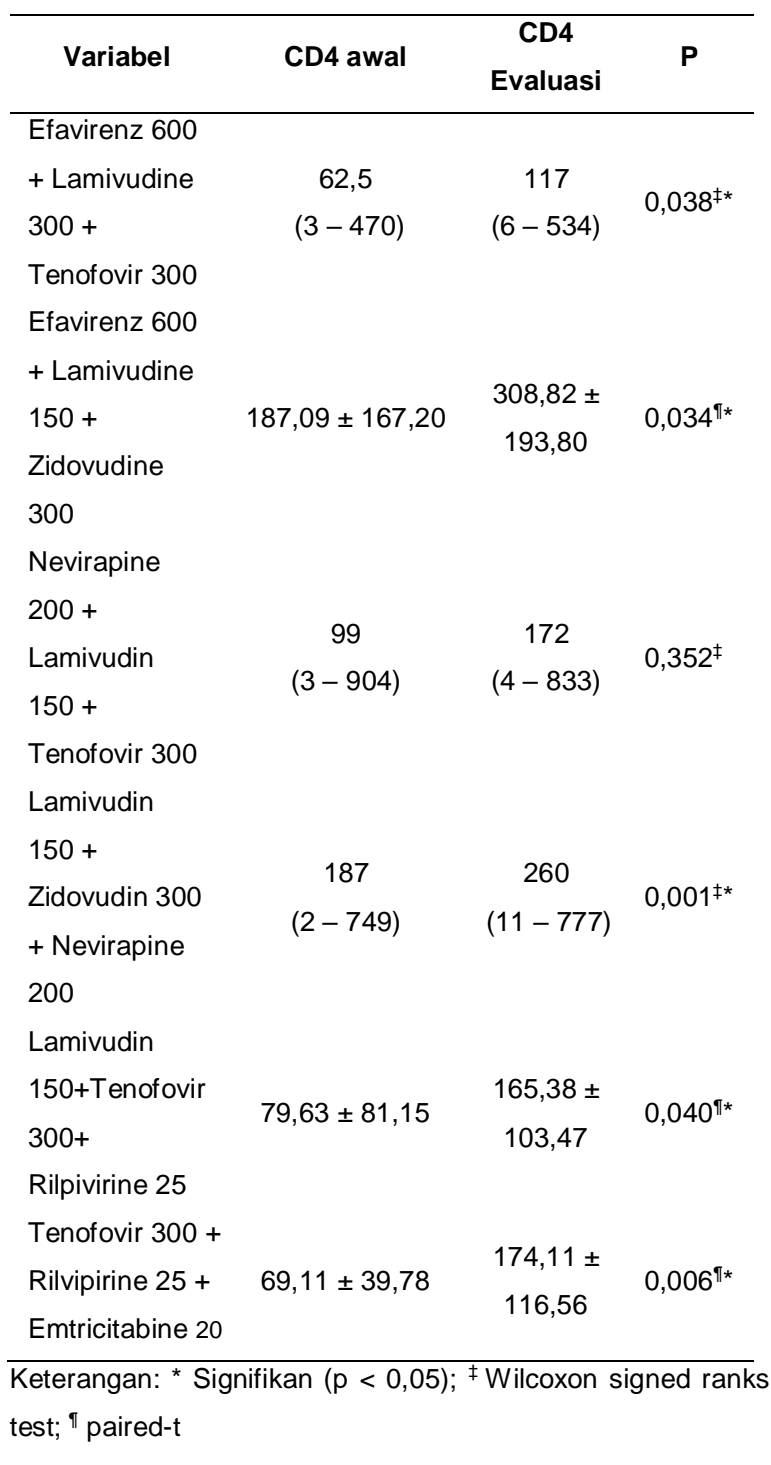

Terdapat peningkatan kadar CD4 yang signifikan secara statistik $(p<0,05)$ antara sebelum mulai kombinasi HAART ke 1,2,4,5,6 dengan sesudah 6 bulan pengobatan HAART. Hanya rejimen kombinasi ketiga yang tidak memiliki peningkatan secara signifikan dimungkinkan dipengaruhi oleh beberapa faktof antara lain periode waktu inisiasi pemberian HAART dan tingkat kepatuhan meminum obat.
Tabel 2. Perbedaan CD4 berdasarkan jenis kombinasi highly active antiretroviral therapy

\begin{tabular}{|c|c|c|}
\hline Variabel & $\begin{array}{c}\text { Median } \\
(\min -\max )\end{array}$ & $p^{\S}$ \\
\hline \multicolumn{3}{|c|}{ CD4 Awal } \\
\hline $\begin{array}{l}\text { Efavirenz } 600+\text { Lamivudine } \\
300+\text { Tenofovir } 300\end{array}$ & $\begin{array}{c}62,5 \\
(3-470)\end{array}$ & 0,412 \\
\hline Efavirenz $600+$ Lamivudine & 191 & \\
\hline $150+$ Zidovudine 300 & $(4-539)$ & \\
\hline Nevirapine 200 + Lamivudin & 99 & \\
\hline $150+$ Tenofovir 300 & $(3-904)$ & \\
\hline Lamivudin 150 + Zidovudin & 187 & \\
\hline $300+$ Nevirapine 200 & $(2-749)$ & \\
\hline Lamivudin $150+$ Tenofovir & 49,5 & \\
\hline 300+ Rilpivirine 25 & $(4-251)$ & \\
\hline $\begin{array}{l}\text { Tenofovir } 300+\text { Rilvipirine } 25+ \\
\text { Emtricitabine } 20\end{array}$ & $\begin{array}{c}62 \\
(2-124)\end{array}$ & \\
\hline \multicolumn{3}{|c|}{ CD4 Evaluasi } \\
\hline $\begin{array}{l}\text { Efavirenz } 600+\text { Lamivudine } \\
300+\text { Tenofovir } 300\end{array}$ & $\begin{array}{c}117 \\
(6-534)\end{array}$ & 0,182 \\
\hline Efavirenz 600 + Lamivudine & 234 & \\
\hline $150+$ Zidovudine 300 & $(42-612)$ & \\
\hline Nevirapine 200 + Lamivudin & 172 & \\
\hline $150+$ Tenofovir 300 & $(4-833)$ & \\
\hline Lamivudin $150+$ Zidovudin & 260 & \\
\hline $300+$ Nevirapine 200 & $(11-777)$ & \\
\hline Lamivudin $150+$ Tenofovir & 168 & \\
\hline 300+ Rilpivirine 25 & $(26-301)$ & \\
\hline $\begin{array}{l}\text { Tenofovir } 300+\text { Rilvipirine } 25+ \\
\text { Emtricitabine } 20\end{array}$ & $\begin{array}{c}155 \\
(29-356)\end{array}$ & \\
\hline \multicolumn{3}{|c|}{ Selisih CD4 } \\
\hline $\begin{array}{l}\text { Efavirenz } 600+\text { Lamivudine } \\
300+\text { Tenofovir } 300\end{array}$ & $\begin{array}{c}37,5 \\
(-173-485)\end{array}$ & 0,482 \\
\hline Efavirenz $600+$ Lamivudine & 202 & \\
\hline $150+$ Zidovudine 300 & $(-214-270)$ & \\
\hline Nevirapine 200 + Lamivudin & 14 & \\
\hline $150+$ Tenofovir 300 & $(-452-830)$ & \\
\hline Lamivudin $150+$ Zidovudin & 113,5 & \\
\hline $300+$ Nevirapine 200 & $(-48-524)$ & \\
\hline Lamivudin $150+$ Tenofovir & 61,5 & \\
\hline $300+$ Rilpivirine 25 & $(-41-265)$ & \\
\hline $\begin{array}{l}\text { Tenofovir } 300+\text { Rilvipirine } 25+ \\
\text { Emtricitabine } 20\end{array}$ & $\begin{array}{c}66 \\
(10-249)\end{array}$ & \\
\hline
\end{tabular}

Keterangan : ${ }^{*}$ Signifikan $(\mathrm{p}<0,05) ;{ }^{\S}$ Kruskal-wallis 
Tidak terdapat perbedaan di antara keenam rejimen HAART dalam menaikkan kadar CD4 setelah 6 bulan pengobatan. Sehingga dapat dikatakan bahwa secara umum rejimen HAART yang direkomendasikan oleh Kementerian Kesehatan RI memberikan luaran terapi yang baik dan sebanding.

\section{Perbandingan efikasi enam jenis kombinasi} HAART terhadap kenaikan jumlah CD4 ratarata

Hasil penelitian ini menunjukkan bahwa efikasi enam jenis kombinasi ARV memiliki efikasi yang baik, karena semuanya memberikan kenaikan jumlah CD4 rata-rata $>50 \mathrm{sel} / \mathrm{mm}^{3}$. Setelah 6 bulan pengobatan ARV diperoleh kenaikan CD4 rata-rata lebih dari 100 $\mathrm{sel} / \mathrm{mm} 3$, hal ini menunjukkan pengobatan ARV memberikan respon imun yang baik pada pasien HIV/AIDS di RSUP Dr.Kariadi Semarang.

Terdapat peningkatan kadar TLC yang signifikan secara statistik $(p<0,05)$ pada keenaam kombinasi HAART antara sebelum pengobatan dengan sesudah 6 bulan pengobatan HAART.

Tidak terdapat perbedaan di antara keenam rejimen HAART dalam menaikkan kadar TLC setelah 6 bulan pengobatan. Sehingga dapat dikatakan bahwa secara umum rejimen HAART yang direkomendasikan oleh Kementerian Kesehatan RI memberikan luaran terapi yang baik dan sebanding.

Grafik 1. Rerata kenaikan CD4 awal dan CD4 Evaluasi dengan 6 jenis kombinasi HAART

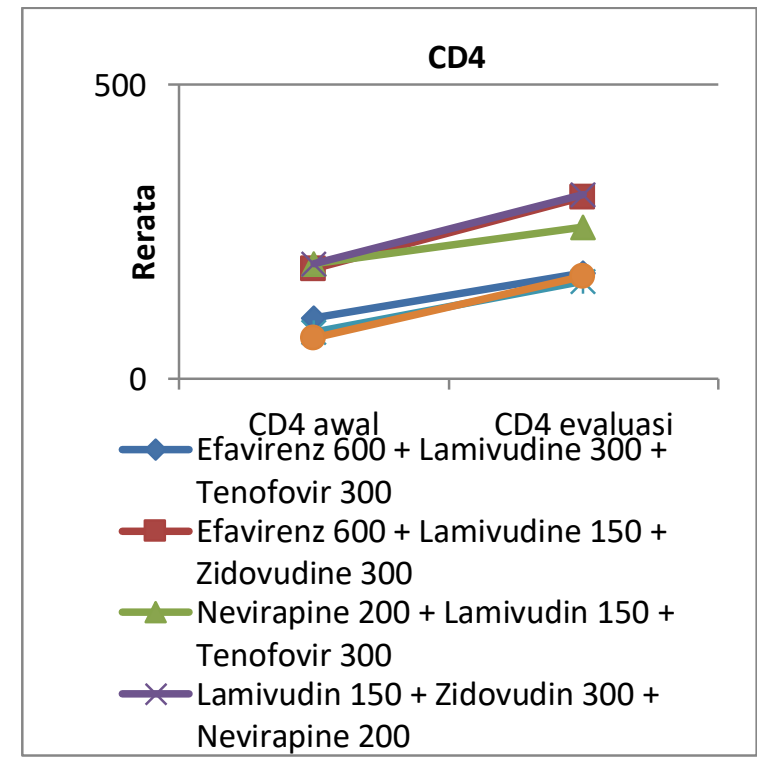

Tabel 3. Uji beda berpasangan total lymphocyte count awal dan total lymphocyte count evaluasi

\begin{tabular}{|c|c|c|c|}
\hline Variabel & $\begin{array}{l}\text { TLC } \\
\text { awal }\end{array}$ & $\begin{array}{c}\text { TLC } \\
\text { Evaluasi }\end{array}$ & $\mathbf{p}$ \\
\hline $\begin{array}{l}\text { Efavirenz } 600+ \\
\text { Lamivudine } 300+ \\
\text { Tenofovir } 300\end{array}$ & $\begin{array}{c}689,5(76- \\
2825)\end{array}$ & $\begin{array}{l}1682,5 \\
(179- \\
7921)\end{array}$ & $0,008^{\ddagger *}$ \\
\hline $\begin{array}{l}\text { Efavirenz } 600+ \\
\text { Lamivudine } 150+ \\
\text { Zidovudine } 300\end{array}$ & $\begin{array}{c}1099,0 \pm \\
691,91\end{array}$ & $\begin{array}{c}2725,55 \pm \\
2061,90\end{array}$ & $0,041^{\mathbb{I} *}$ \\
\hline $\begin{array}{l}\text { Nevirapine } 200+ \\
\text { Lamivudin } 150+ \\
\text { Tenofovir } 300\end{array}$ & $\begin{array}{c}1008(510- \\
4686)\end{array}$ & $\begin{array}{l}1820 \\
(641- \\
4693)\end{array}$ & $0,031^{\ddagger *}$ \\
\hline $\begin{array}{l}\text { Lamivudin } 150+ \\
\text { Zidovudin } 300+ \\
\text { Nevirapine } 200\end{array}$ & $\begin{array}{c}1621,20 \pm \\
1095,23\end{array}$ & $\begin{array}{c}3413,60 \pm \\
1871,01\end{array}$ & $<0,001^{\text {I** }}$ \\
\hline $\begin{array}{l}\text { Lamivudin } \\
\text { 150+Tenofovir 300+ } \\
\text { Rilpivirine } 25\end{array}$ & $\begin{array}{c}866,13 \pm \\
535,71\end{array}$ & $\begin{array}{c}2505,63 \pm \\
2083,54\end{array}$ & $0,041^{\mathbb{I} *}$ \\
\hline $\begin{array}{l}\text { Tenofovir } 300+ \\
\text { Rilvipirine } 25+ \\
\text { Emtricitabine } 20\end{array}$ & $\begin{array}{c}2011,44 \pm \\
1133,73\end{array}$ & $\begin{array}{c}3440,33 \pm \\
1720,76\end{array}$ & $0,014^{\mathbb{f} *}$ \\
\hline
\end{tabular}

Keterangan : * Signifikan $(p<0,05) ;{ }^{\ddagger}$ Wilcoxon signed ranks test; " Paired t

Hasil penelitian ini menunjukkan bahwa efikasi enam jenis kombinasi ARV memiliki efikasi yang baik, karena semuanya memberikan kenaikan jumlah TLC rata-rata > $1200 \mathrm{sel} / \mathrm{mm}^{3}$. Hal ini menunjukkan pengobatan ARV memberikan respon imun yang baik pada pasien HIV/AIDS di RSUP Dr.Kariadi Semarang.

Imunitas tubuh terkait dengan infeksi HIV secara klinis dapat diketahui berdasarkan kadar CD4. Pemberian terapi bertujuan untuk meningkatkan kadar CD4 pada pasien HIV. ${ }^{3}$ Sebanyak 89 pasien yang menjadi sampel pada penelitian ini. Berdasarkan hasil penelitian ini apabila sampel dibagi menurut jenis regimen terapi selalu terdapat kenaikan kadar CD4 pada tiap-tiap kelompok. 
Tabel 4. Perbedaan total lymphocyte count berdasarkan jenis kombinasi highly active antiretroviral therapy

\begin{tabular}{|c|c|c|}
\hline Variabel & $\begin{array}{c}\text { Median } \\
(\min -\max )\end{array}$ & $\mathbf{p}^{\S}$ \\
\hline \multicolumn{3}{|c|}{ TLC Awal } \\
\hline $\begin{array}{l}\text { Efavirenz } 600+ \\
\text { Lamivudine } 300+ \\
\text { Tenofovir } 300\end{array}$ & $\begin{array}{c}689,5 \\
(76-2825)\end{array}$ & 0,068 \\
\hline $\begin{array}{l}\text { Efavirenz } 600+ \\
\text { Lamivudine } 150+ \\
\text { Zidovudine } 300\end{array}$ & $\begin{array}{c}1050 \\
(162-2659)\end{array}$ & \\
\hline $\begin{array}{l}\text { Nevirapine } 200+ \\
\text { Lamivudin } 150+ \\
\text { Tenofovir } 300\end{array}$ & $\begin{array}{c}1008 \\
(510-4686)\end{array}$ & \\
\hline $\begin{array}{l}\text { Lamivudin } 150+ \\
\text { Zidovudin } 300+ \\
\text { Nevirapine } 200\end{array}$ & $\begin{array}{c}1462,5 \\
(137-3881)\end{array}$ & \\
\hline Lamivudin $150+$ Tenofovir & 772,5 & \\
\hline 300+ Rilpivirine 25 & $(237-1570)$ & \\
\hline $\begin{array}{l}\text { Tenofovir } 300+ \\
\text { Rilvipirine } 25+ \\
\text { Emtricitabine } 20\end{array}$ & $\begin{array}{c}1761 \\
(540-3754)\end{array}$ & \\
\hline \multicolumn{3}{|c|}{ TLC Evaluasi } \\
\hline $\begin{array}{l}\text { Efavirenz } 600+ \\
\text { Lamivudine } 300+ \\
\text { Tenofovir } 300\end{array}$ & $\begin{array}{c}1682,5 \\
(179-7921)\end{array}$ & 0,067 \\
\hline $\begin{array}{l}\text { Efavirenz } 600+ \\
\text { Lamivudine } 150+ \\
\text { Zidovudine } 300\end{array}$ & $\begin{array}{c}1952 \\
(263-6335)\end{array}$ & \\
\hline $\begin{array}{l}\text { Nevirapine } 200+ \\
\text { Lamivudin } 150+ \\
\text { Tenofovir } 300\end{array}$ & $\begin{array}{c}1820 \\
(641-4693)\end{array}$ & \\
\hline $\begin{array}{l}\text { Lamivudin } 150+ \\
\text { Zidovudin } 300+ \\
\text { Nevirapine } 200\end{array}$ & $\begin{array}{c}3870,5 \\
(487-6397)\end{array}$ & \\
\hline $\begin{array}{l}\text { Lamivudin } 150+\text { Tenofovir } \\
300+\text { Rilpivirine } 25\end{array}$ & $\begin{array}{c}1906 \\
(302-5232)\end{array}$ & \\
\hline $\begin{array}{l}\text { Tenofovir } 300+ \\
\text { Rilvipirine } 25+ \\
\text { Emtricitabine } 20\end{array}$ & $\begin{array}{c}2966 \\
(1310-6381) \\
\end{array}$ & \\
\hline \multicolumn{3}{|c|}{ Selisih TLC } \\
\hline $\begin{array}{l}\text { Efavirenz } 600+ \\
\text { Lamivudine } 300+ \\
\text { Tenofovir } 300\end{array}$ & $\begin{array}{c}650 \\
(-2146-6374)\end{array}$ & 0,230 \\
\hline $\begin{array}{l}\text { Efavirenz } 600+ \\
\text { Lamivudine } 150+ \\
\text { Zidovudine } 300\end{array}$ & $\begin{array}{c}807 \\
(-1251-5326)\end{array}$ & \\
\hline $\begin{array}{l}\text { Nevirapine } 200+ \\
\text { Lamivudin } 150+ \\
\text { Tenofovir } 300\end{array}$ & $\begin{array}{c}510 \\
(-1948-2169)\end{array}$ & \\
\hline $\begin{array}{l}\text { Lamivudin } 150+ \\
\text { Zidovudin } 300+ \\
\text { Nevirapine } 200\end{array}$ & $\begin{array}{c}1456,5 \\
(-271-4595)\end{array}$ & \\
\hline $\begin{array}{l}\text { Lamivudin } 150+\text { Tenofovir } \\
300+\text { Rilpivirine } 25\end{array}$ & $\begin{array}{c}1501,5 \\
(-267-4447)\end{array}$ & \\
\hline $\begin{array}{l}\text { Tenofovir } 300+ \\
\text { Rilvipirine } 25+ \\
\text { Emtricitabine } 20\end{array}$ & $\begin{array}{c}1197 \\
(-293-3511)\end{array}$ & \\
\hline
\end{tabular}

Keterangan : * Signifikan $(p<0,05) ;{ }^{\S}$ Kruskal-wallis
Grafik 2. Rerata kenaikan TLC awal dan TLC evaluasi dengan 6 jenis kombinasi HAART

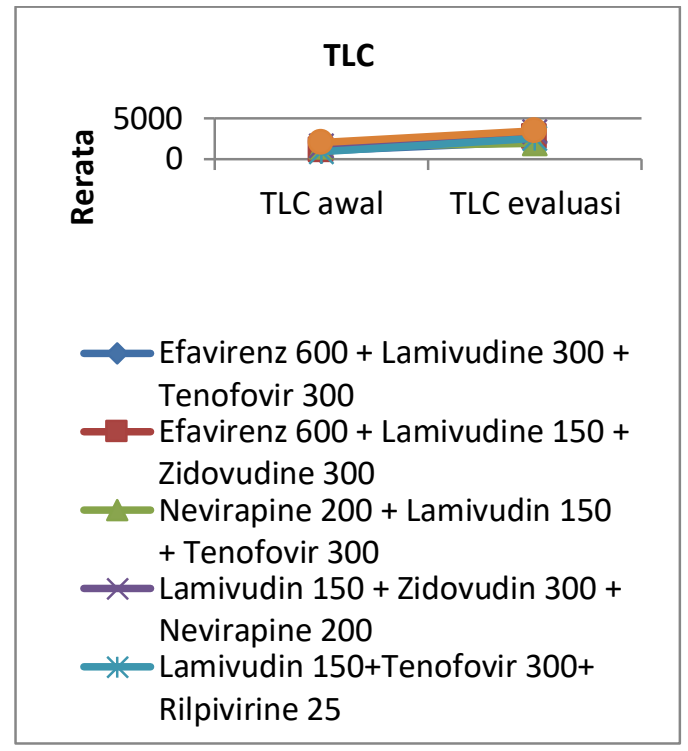

\section{PEMBAHASAN}

Pada penilaian statistik untuk kenaikan kadar CD4 tertinggi dialami pasien dengan regimen terapi Efavirenz + Lamivudine+ Zidovudine dengan rerata kenaikan 121,73 (SD = 164,48). Kenaikan tertinggi kedua dialami oleh pasien dengan regimen terapi Lamivudin + Zidovudin + Nevirapine dengan rerata kenaikan 117,00 (SD=136,76). Pasien dengan regimen terapi Nevirapine + Lamivudin + Tenofovir mengalami kenaikan kadar CD4 terendah dengan rata-rata kenaikan sebesar 62,41 (SD=305,41). Pada penilaian statistik untuk kenaikan kadar TLC tertinggi dialami pasien dengan regimen terapi Lamivudin + Zidovudin + Nevirapine dengan rerata kenaikan 1792,40 (SD=1451,40). Kenaikan tertinggi kedua dialami oleh pasien dengan regimen terapi Efavirenz + Lamivudine + Zidovudine 1626,55 (SD=2296,53). Pasien dengan regimen terapi Nevirapine + Lamivudin+ Tenofovir mengalami kenaikan kadar TLC terendah dengan rata-rata kenaikan sebesar 473,94 $(\mathrm{SD}=986,52)$.

Kenaikan CD4 dan TLC rata-rata yang berbeda anatara keenam regimen HAART ini tidak menunjukkan perbedaan yang bermakna secara statistik antara jenis kombinasi HAART yang diterima pasien dengan kadar CD4 $(p=0,482){ }^{*}$ Signifikan $(p<$ $0,05)$ maupun TLC $(p=0,230){ }^{\star}$ Signifikan $(p<0,05)$. 
Kombinasi stavudine (d4T), 3TC dan NVP (Nevirapine + Lamivudin + Tenofovir) adalah rejimen lini pertama yang direkomendasikan WHO untuk pengobatan pasien yang terinfeksi $\mathrm{HIV}-1 .^{3}$ tidak ditentukannya jenis HIV pada pasien yang menerima regimen kombinasi HAART di RSUP Dr. Kariadi mungkin menjadi salah satu faktor yang mempengaruhi rendahnya kenaikan CD4 pada regimen kombinasi ini.

\section{SIMPULAN}

Keenam jenis kombinasi ARV mempunyai efikasi yang baik ditinjau dari kenaikan jumlah CD4 rata-rata dan TLC rata-rata dengan $p<0,05$ setelah 6 bulan pengobatan di RSUP Dr. Kariadi Semarang bulan mei 2018 - mei 2019.

Tidak terdapat perbedaan pada jenis pemberian kombinasi Highly Active Antiretroviral Therapy dengan perubahan kadar CD4 dan Total Lymphocyte Count ( $p>0,05)$ pada pada pasien HIV/AIDS di RSUP Dr. Kariadi Semarang.

Berdasarkan hasil pengujian dan pembahasan pada penelitian diatas dapat disimpulkan bahwa terdapat perbedaan yang signifikan kadar CD4 dan TLC sebelum dan setelah terapi HAART enam bulan pada pasien HIV-AIDS di RSUP Dr.Kariadi Semarang, sedangkan untuk jenis kombinasi regimen tidak terdapat perbedaan yang signifikan.

\section{UCAPAN TERIMA KASIH}

Terima kasih kepada pihak Rumah Sakit RSUP Dr. Kariadi semarang, Bagian Patologi Klinik FK Universitas Diponegoro dan semua pihak yang telah membantu untuk proses penyelesaian penelitian ini.

\section{KEPUSTAKAAN}

1. Kementrian Kesehatan RI. Pedoman nasional tatalaksana klinis infeksi HIV dan terapi antiretroviral pada orang dewasa. Jakarta: Kementrian Kesehatan RI; 2011.

2. Kementrian Kesehatan RI. Laporan perkembangan HIV AIDS \& penyakit infeksi menular seksual (PIMS) Triwulan II Tahun 2019. Jakarta: Kementrian Kesehatan RI.
3. World Health Organization (WHO). Policy brief: consolidated guidelines on HIV prevention, diagnosis, treatment and care for key populations. World Health Organization; 2017.

4. Gall J, Sabin K, Frescura L, Sabin ML, Erkkola T, Toskin I. Global trends of monitoring and data collection on the HIV response among key populations since the 2001 UN declaration of commitment on HIV/AIDS. AIDS and Behavior. 2017 Jul 1; 21(1):34-43.

5. Utami IR, Sriatmi A, Wigati PA. Aplikasi fungsi manajemen pengelola layanan komprehensif berkesinambungan HIV-IMS Puskesmas di Kota Semarang tahun 2014. Jurnal Kesehatan Masyarakat. 2015 Mar 2;3(1).

6. Haghdoost A, Karamouzian M. Zero new HIV infections, zero discrimination, and zero AIDSrelated deaths: feasible goals or ambitious visions on the occasion of the world AIDS day?. International journal of preventive medicine. 2012 Dec;3(12):819.

7. Hughes AJ. On the road to zero in San Francisco: understanding population dynamics, HIV transmission and internalized HIV stigma in order to get to zero HIV transmission, zero HIV-related deaths and zero HIV stigma [dissertation] UC Berkeley;2016.

8. Abuelezam NN, McCormick AW, Surface ED, Fussell T, Freedberg KA, Lipsitch M, Seage GR. Modelling the epidemiologic impact of achieving UNAIDS fast-track 90-90-90 and 95-95-95 targets in South Africa. Epidemiology \& Infection. 2019; 147.

9. Des Derivanti A, Wulandari MP, Antoni A. Study of the effect of family communication and therapeutic communication on anxiety ODHA. WACANA, Jurnal Sosial dan Humaniora. 2017;20(2).

10. Karyadi TH. Keberhasilan pengobatan antiretroviral. Jurnal Penyakit Dalam Indonesia; 2017 Maret;4(1).

11. Puspitasari WD, Yasin NM, Rahmawati F. Perbandingan luaran terapi rejimen antiretroviral lini kedua pada pasien HIV/AIDS. JMPF. 2018, September;8(3):19-27. 
12. Hoffman, Rockstroh, Kamps. HIV Medicine 2007. Edisi ke-15. Paris: Flying Publisher.hlm.705-30.

13. Mbanya D, Assah F, Ndembi N, Kaptue L. Monitoring antiretroviral therapy in HIV/AIDS patients in resource-limited settings: CD4 counts or total lymphocyte counts? International Journal of Infectious Diseases. 2007 Mar 1;11(2):157-60.

14. Huibers MH, Moons P, Maseko N, Gushu MB, Wit FW, Graham SM, van Hensbroek MB, Calis JC. An evaluation of alternative markers to guide initiation of anti-retroviral therapy in HIV-infected children in settings where CD4 assays are not available. Journal of tropical pediatrics. 2015 Oct 21; 62(1): 19-28.

15. Kumarasamy N, Mahajan AP, Flanigan TP, Hemalatha R, Mayer $\mathrm{KH}$, Carpenter CC, Thyagarajan SP, Solomon S. Total lymphocyte count (TLC) is a useful tool for the timing of opportunistic infection prophylaxis in India and other resource-constrained countries. JAIDS Journal of Acquired Immune Deficiency Syndromes. 2002 Dec 1;31(4):378-83.
16. Shapiro NI, Karras DJ, Leech SH, Heilpern KL. Absolute lymphocyte count as a predictors of CD4 count. Ann Emerg Med. 1998; 32: 323-8.

17. Kementrian Kesehatan RI. Pedoman pelaksanaan pencegahan penularan HIV dan sifilis dari ibu ke anak bagi tenaga kesehatan. Jakarta: Kementrian Kesehatan RI; 2014.hlm.8-9.

18. Tambunan B. Perbandingan jumlah limfosit cd4 metode imunofluorescence dengan metode flowcytometri [Program Pendidikan Dokter Spesialis Patologi Klinik\}. UNS; 2015.hlm.1-11.

19. Rahmadani Y, Andrajati R, Andalusa R. Perbandingan efikasi beberapa kombinasi antiretroviral pada pasien HIV/AIDS ditinjau dari kenaikan jumlah CD4 rata-rata. Majalah IImu Kefarmasian; 2008;2(5):27-64.

20. Rosen S, Maskew M, Larson BA, Brennan AT, Tsikhutsu I, Fox MP, Vezi L, Bii M, Venter WD. Simplified clinical algorithm for identifying patients eligible for same-day HIV treatment initiation (SLATE): Results from an individually randomized trial in South Africa and Kenya. PLoS medicine. 2019 Sep;16(9). 